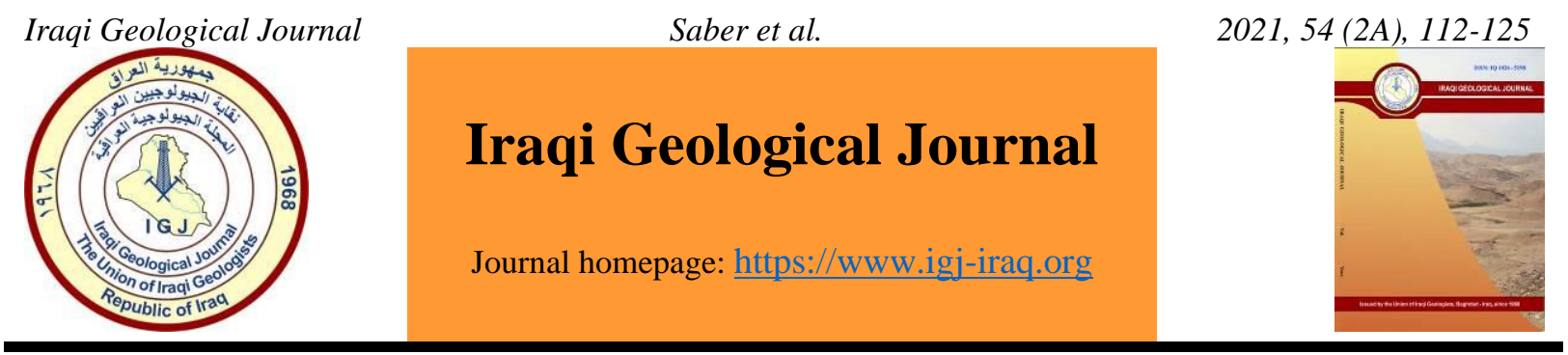

\title{
Vertical and Lateral Distribution of Heavy Metals in the Euphrates River Sediments between Heet and Fallujah, Western Iraq
}

\author{
Mohammed Saber ${ }^{1}$, Wahran M. Saod ${ }^{2, *}$ and Emad Abdulrahman Al-Heety ${ }^{3}$ \\ ${ }^{1}$ Anbar Water Directorate, Ministry of Water Resources, Anbar, Iraq \\ ${ }^{2}$ Department of Chemistry, College of Science, University of Anbar, Anbar, Iraq \\ ${ }^{3}$ Department of Applied Geology, College of Science, University of Anbar, Anbar, Iraq \\ *Correspondence: sc.wahran.s@uoanbar.edu.iq
}

Received: 29 March 2021; Accepted: 9 May 2021; Published: 31 July 2021

\begin{abstract}
The present work aims to investigate the vertical and lateral distribution of heavy metals and to assess pollution level in the Euphrates River sediments along the area extended between Heet to Fallujah cities in October 2020. The sediment samples were collected from five sites and three depths range $0-30 \mathrm{~cm}, 30-60 \mathrm{~cm}$, and $60-90 \mathrm{~cm}$. The concentration of heavy metals sediment samples was compared with reference values. The results showed that the mean concentrations of heavy metals take the following ascending order: cadmium $(1.8 \mathrm{mg} / \mathrm{kg})$, lead $(12.48 \mathrm{mg} / \mathrm{kg})$, Cobalt $(16 \mathrm{mg} / \mathrm{kg})$, copper $(24.88 \mathrm{mg} / \mathrm{kg})$, chromium $(46.07 \mathrm{mg} / \mathrm{kg})$, zinc $(58.75 \mathrm{mg} / \mathrm{kg})$ and nickel $(114.44 \mathrm{mg} / \mathrm{kg})$. The results did not show a similar vertical distribution pattern of heavy metals among the five sampling sites. The cadmium showed high enrichment compared to the other metals that showed low to moderate enrichment according to reference values. The contamination factor and geoaccumulation index showed high contamination with $\mathrm{Cd}$, moderate with $\mathrm{Ni}$ and low with other metals.
\end{abstract}

Keywords: Heavy metals; Pollution; Sediments; Euphrates

\section{Introduction}

In recent decades, significant attention has been paid to heavy metal contamination as a dangerous environmental problem because of the toxicity, abundance, persistence and bioaccumulation of these elements (Chen et al., 2016,) (Islam et al., 2017 and ) (Jin et al., 2019). In general, the contamination state of the environment is evaluated by the total concentration of heavy metals (Kanda et al., 2018). The riverine sediments are considered as the main basins for various pollutants following the largely uncontrolled discharge of contamination resulting from human activities and geogenic processes (Liu et al., 2018). The sediment contamination is an important indicator of environmental variation as a result of anthropogenic influence (Gao et al., 2019). River sediments serve as not only a major sink and carrier of heavy metals but also as potential sources of secondary pollution, which can reflect their contamination level (Tang et al., 2014 and ) (Hsu et al., 2016). The heavy metals are released into the aquatic environments from geogenic and anthropogenic sources. The geogenic sources include chemical leaching of bedrock, water drainage basins and runoff from banks (Raj et al., 2017). The anthropogenic sources of heavy metals pollution in aquatic systems include mining activities, industrial wastes disposal and pesticides use, (Chakravarty \& Patgiri, 2009). The heavy metals pollution of sediments is DOI: $10.46717 /$ igj.54.2A.9Ms-2021-07-30 
an indicator of the aquatic systems water quality (Zhao et al., 2012). The heavy metal distribution in sediments and pollution levels supplies a base for consideration of sediments treatment methods and evaluation of the potential releasing of heavy metals into water and transport downstream (Nawrot et al., 2020). The vertical and spatial distribution of heavy metals and pollution levels have been evaluated in sediments of many world rivers, such as the Yinma River, China (Guan et al., 2018), the Voghji River, Armenia (Gabrielyan et al., 2018), the Barigui River, Brazil (Machado et al., 2017), the Harazdan River, Armenia (Petrosyan et al., 2019), the Thames River, the UK (Vane et al., 2020), the Yang River, China (Tang et al., 2020), and the Lu Lu River, China (Ye et al., 2020). The spatial distribution of heavy metals in sediments of the Euphrates River in Iraq has been investigated by many authors (Issa \& Qanbar, 2016); (Al-Taher et al., 2020); and (Hussain \& Al-Jaberi, 2020). The spatial variation of heavy metal concentrations in sediments of the Euphrates River along the studied area between Heet and Ramadi Cities has been studied by (Al-Bassam \& Al-Mukhtar, 2008) and (Salah et al., 2012). The aim of the study is to investigate how heavy metals are laterally and vertically distributed in sediments of the given study area of Euphrates River between Heet and Fallujah Cities. This study represents the first attempt to investigate the vertical distribution of heavy metals in the Euphrates River sediments.

\section{Materials and Methods}

\subsection{Sediment Sampling}

The sediment samples were collected from five sites located between Heet and Fallujah Cities, (Table 1) and (Fig. 1). The sediments were sampled from three depth ranges (0-30, 30-60, and 60-90 $\mathrm{cm})$ using an auger tube sampling device.

Table 1. Location of sampling sites in the study area

\begin{tabular}{lccc}
\hline Sampling region & Sampling site & Latitude (N) & Longitude (E) \\
\hline Heet & S1 & $33.649730^{\circ}$ & $42.817123^{\circ}$ \\
Muhammadi & S2 & $33.565374^{\circ}$ & $42.900063^{\circ}$ \\
Ramadi & S3 & $33.441916^{\circ}$ & $43.315409^{\circ}$ \\
Khalidiya & S4 & $33.397504^{\circ}$ & $43.523923^{\circ}$ \\
Fallujah & S5 & $33.337579^{\circ}$ & $43.762461^{\circ}$ \\
\hline
\end{tabular}

\subsection{Sample Preparation and Analysis}

The samples were dried and then inserted into the oven at a temperature of 70 degrees Celsius for a period of 24 hours. The sediment samples were crushed with ceramic mortar (Agate) and homogenized, then sieved with a $150 \mu \mathrm{m}$ steel sieve for digestion (EPA Method 3050B, 2012) (Islam et al., 2015). A mixture of digesting sediments from concentrated acids (hydrochloric acid, and nitric acid) was prepared at a ratio of 3:1 respectively, (or Aqua Regia solution). Then, 1 gram of the dry sample was weighed and $10 \mathrm{ml}$ of the prepared lemon mixture was added to it and the sample was stirred. Next, the mixture was put in a microwave and digested for 15 minutes to near dry at a temperature of $1900 \mathrm{C}$, after which it was to cool down and washed with deionized water several times until the entire sample was removed. It was then filtered with Whiteman $(42 \mathrm{Mm})$ filter paper and the volume were topped up with distilled water to make 50ml (Islam et al., 2015). The digested samples are analyzed for $\mathrm{Zn}, \mathrm{Cu}, \mathrm{Fe}, \mathrm{Cr}$, $\mathrm{Co}, \mathrm{Ni}, \mathrm{pb}$ and Cd using Atomic Absorption Flame Emission Spectrophotometer (ASC.7000) at Anbar Water Directorate, Central Water Laboratory. 


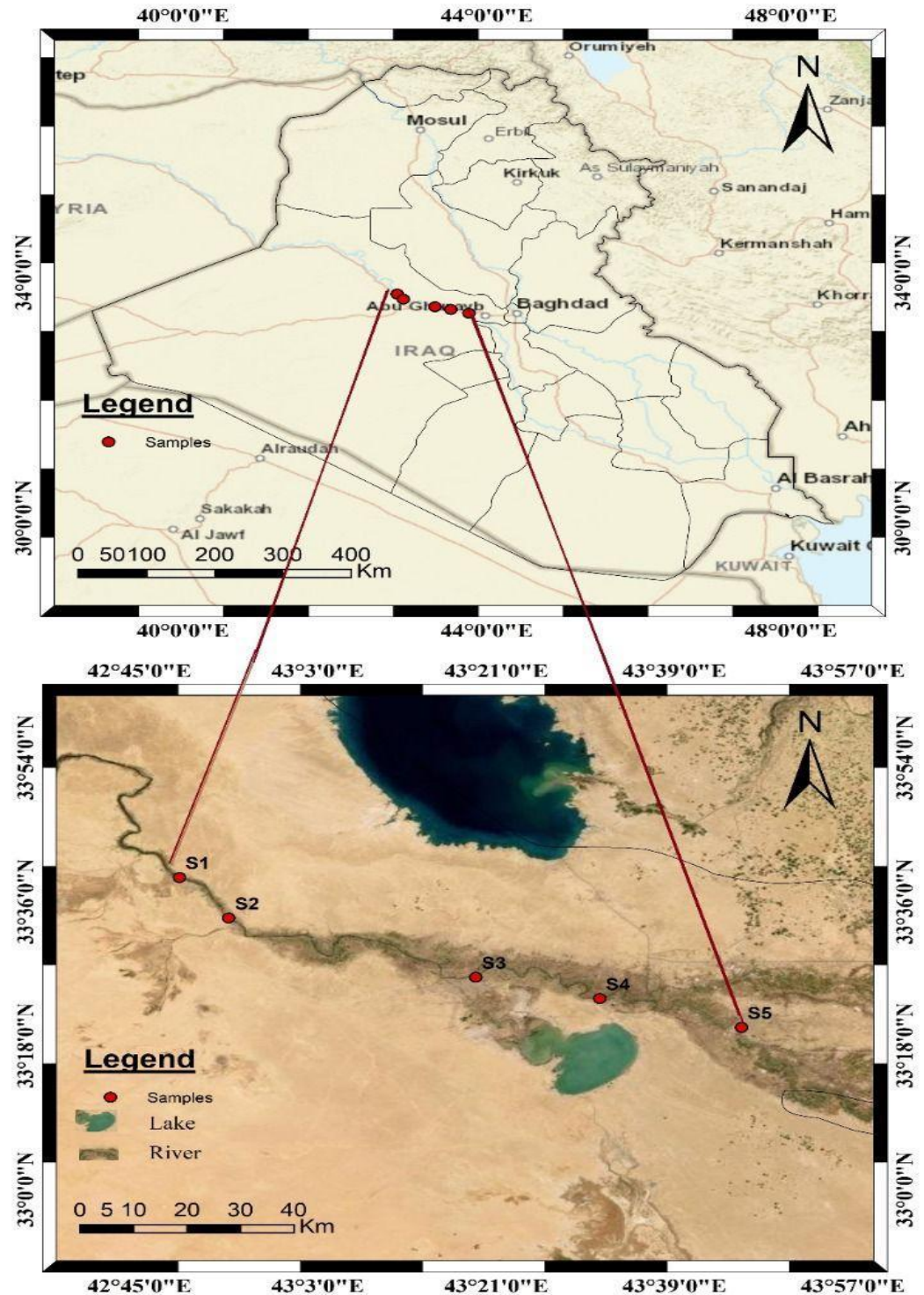

Fig.1. Location map of the study area and sediment sampling sites

\subsection{Pollution Level}

The enrichment factor (EF), the geo-accumulation Index (Igeo), the contamination factor (CF), and the pollution load index (PLI) were used to evaluate level contamination by heavy metals in the studied stations. Specific to each of these measures, the values were calculated, as well as the specific levels for each of them. These levels were collected from many data sources related to pollution phenomena, and from these data the pollution limits were determined low, high, or severe. International reference values were used for the elements in our study (Martin \& Meybeck, 1979)

Enrichment Factor $(\mathrm{EF})=\mathrm{Cm} / \mathrm{CFe}$ sample $) /(\mathrm{Cm} / \mathrm{CFe}$ ) background (Sinex \& Helz, 1981)

$\mathrm{Cm}=$ element concentration in sample

$\mathrm{CFe}=$ Concentration of Iron

Geo-accumulation Index $($ Igeo $)=\log 2[\mathrm{Cm}$ Sample/ $(1.5 \times \mathrm{Cm}$ Background $)]$

$($ I geo $)=\operatorname{Ln}\{\mathrm{Cm} / 1.5 * \mathrm{CmB}\}($ dos Santos et al., 2017)

$\mathrm{Cm}=$ element concentration in sample

$\mathrm{CmB}=$ the reference value of the element.

Contamination factor $(\mathrm{CF})=\mathrm{Cm} / \mathrm{Bn}$ (Müller, 1969) 
$\mathrm{Bn}=$ the reference value of the element in nature

$\mathrm{Cm}=$ element concentration in sample

$$
\mathrm{PLI}=(\mathrm{CF} 1 \times \mathrm{CF} 2 \times \mathrm{CF} 3 \times \ldots \ldots \mathrm{CFn}) 1 / \mathrm{n}(\text { Mmolawa et al., 2011) }
$$

$\mathrm{n}=$ number of elements

\section{Results and Discussion}

\subsection{Heavy Metal Concentrations in Sediment}

The results of analysis of heavy metals in sediment sample of the Euphrates River are listed in Table 2. The results showed that $\mathrm{Pb}$ concentration ranges from 8.79 and 17.14 with mean of 12.48 $\mathrm{mg} / \mathrm{kg}$. This is less than previous studies in the sediments of the Euphrates River in study area (Salah et al., 2012). As for Cd concentrations ranges from 1.129 and 3.255 , mean of $1.8 \mathrm{mg} / \mathrm{kg}$. The results obtained were lower than that's of the previous studies of the Euphrates River sediments (Salah et al., 2012; Al-bassam, 2011). The Fe concentration in sediment of the Euphrates River ranges from 15900 and 28692 , mean of $24969 \mathrm{mg} / \mathrm{kg}$. The results were higher than previous studies of the Euphrates River (Salah et al., 2012). In addition, $\mathrm{Cu}$ concentration in sediment of the Euphrates River stations ranges from 17.61 and 40.81 , mean of $24.88 \mathrm{mg} / \mathrm{kg}$. These results were comparable to previous studies of the Euphrates River (Al-Bassam \& Al-Mukhtar, 2008), while the values of $\mathrm{Cu}$ concentrations in the current study were higher than in a previous study (Salah et al., 2012). While $\mathrm{Zn}$ concentrations ranges from 42.68 and 75.85 , mean of $58.75 \mathrm{mg} / \mathrm{kg}$. The results of $\mathrm{Zn}$ concentrations were lower in previous studies of the Euphrates River (Al-Bassam \& Al-Mukhtar, 2008; Salah et al., 2012). As for the Cr concentration in sediment of the Euphrates River stations ranged between 30.48 and 59.88 , mean of $46.07 \mathrm{mg} / \mathrm{kg}$.

Table 2. Concentration of heavy metals $(\mathrm{mg} / \mathrm{kg})$ in sediment samples of Euphrates River

\begin{tabular}{ccccccccccc}
\hline No & Station & Depth & Pb & Cd & Fe & Cu & Zn & Cr & Ni & Co \\
\hline 1 & \multirow{3}{*}{ S1 } & S.H.30 & 12.13 & 2.895 & 15900 & 18.326 & 42.68 & 30.480 & 62.064 & 11.12 \\
2 & S.H.60 & 15.13 & 3.255 & 16741 & 18.929 & 75.85 & 33.671 & 65.507 & 11.23 \\
3 & & S.H.90 & 14.80 & 3.075 & 18908 & 22.245 & 69.33 & 37.379 & 72.269 & 11.55 \\
4 & & S.M.30 & 8.79 & 1.1820 & 26833 & 17.663 & 46.04 & 47.987 & 104.05 & 14.81 \\
5 & \multirow{2}{*}{ S2 } & S.M.60 & 10.79 & 1.9009 & 22135 & 17.603 & 62.92 & 47.125 & 85.485 & 13.21 \\
6 & & S.M.90 & 10.45 & 1.4681 & 27612 & 20.195 & 47.48 & 50.143 & 95.628 & 14.93 \\
7 & & S.R.30 & 9.78 & 1.1655 & 26097 & 19.532 & 49.25 & 46.262 & 117.76 & 16.35 \\
8 & S3 & S.R.60 & 9.45 & 1.1582 & 27115 & 23.872 & 48.72 & 40.484 & 120.095 & 15.92 \\
9 & & S.R.90 & 9.12 & 1.1291 & 26453 & 25.213 & 48.33 & 39.967 & 138.291 & 16.47 \\
10 & & S.K.30 & 10.45 & 1.2107 & 28692 & 21.159 & 57.73 & 39.794 & 118.742 & 16.84 \\
11 & \multirow{2}{*}{ S4 } & S.K.60 & 12.46 & 1.5077 & 25984 & 25.500 & 57.44 & 52.558 & 131.713 & 17.95 \\
12 & & S.K.90 & 14.80 & 1.6975 & 28218 & 28.394 & 62.91 & 50.661 & 137.369 & 18.62 \\
13 & & S.F.30 & 17.14 & 1.9543 & 27880 & 35.989 & 72.48 & 57.301 & 146.959 & 19.91 \\
14 & \multirow{2}{*}{ S5 } & S.F.60 & 16.82 & 1.8446 & 28269 & 40.812 & 70.35 & 59.889 & 158.946 & 20.28 \\
15 & & S.F.90 & 15.13 & 1.5713 & 27691 & 37.798 & 69.81 & 57.474 & 161.774 & 20.77 \\
\hline
\end{tabular}

These results are comparable to previous studies in the Euphrates River (Al-Bassam \& Al-Mukhtar, 2008), while they were less than in one other study (Salah et al., 2012). While, Co concentrations ranges from 11.12 and 20.77 , mean of $16 \mathrm{mg} / \mathrm{kg}$. The results that we obtained were lower due to an approach to previous studies of the Euphrates River (Al-Bassam \& Al-Mukhtar, 2008; Salah et al., 2012). As for The Ni concentration in sediment samples of the Euphrates River stations ranges from 62.06 and 161.77 mean of $114.44 \mathrm{mg} / \mathrm{kg}$. The results of $\mathrm{Ni}$ obtained in our study were higher due to an 
approach to previous studies of the Euphrates River (Al-Bassam \& Al-Mukhtar, 2008; Salah et al., 2012). Results of correlation matrix analysis for heavy metals in the sediment of Euphrates River are listed in Table 3. The correlation coefficient shows a significant positive relation between chromium with nickel, copper, and cobalt. A significant positive correlation between copper with zinc and lead, Also a positive correlation between nickel with iron and cobalt, addition to a positive correlation between cobalt and iron, at $(\mathrm{P}<0.05$ ), (Table 3), which is evidence of a common source for these elements, the origin of the geological rock (Varol et al., 2020).

Table 3. Correlation matrix analysis of elements in sediments

\begin{tabular}{ccccccccc}
\hline Element & $\mathbf{C d}$ & $\mathbf{C r}$ & $\mathbf{C u}$ & $\mathbf{N i}$ & $\mathbf{Z n}$ & $\mathbf{P b}$ & $\mathbf{C o}$ & $\mathbf{F e}$ \\
\hline $\mathrm{Cd}$ & 1.00 & & & & & & & \\
$\mathrm{Cr}$ & -0.45 & 1.00 & & & & & & \\
$\mathrm{Cu}$ & -0.12 & $\mathbf{0 . 7 3}$ & 1.00 & & & & & \\
$\mathrm{Ni}$ & $\mathbf{- 0 . 6 3}$ & $\mathbf{0 . 7 8}$ & $\mathbf{0 . 8 2}$ & 1.00 & & & & \\
$\mathrm{Zn}$ & 0.47 & 0.33 & $\mathbf{0 . 5 4}$ & 0.20 & 1.00 & & & \\
$\mathrm{~Pb}$ & $\mathbf{0 . 5 6}$ & 0.38 & $\mathbf{0 . 7 0}$ & 0.24 & $\mathbf{0 . 8 5}$ & 1.00 & & \\
$\mathrm{Co}$ & $\mathbf{- 0 . 6 0}$ & $\mathbf{0 . 8 4}$ & $\mathbf{0 . 8 3}$ & $\mathbf{0 . 9 8}$ & 0.24 & 0.32 & 1.00 & \\
$\mathrm{Fe}$ & $\mathbf{- 0 . 8 6}$ & $\mathbf{0 . 7 3}$ & 0.49 & $\mathbf{0 . 8 4}$ & -0.08 & -0.11 & $\mathbf{0 . 8 5}$ & 1.00 \\
\hline
\end{tabular}

Marked correlations are significant at $\mathrm{p}<0.05$.

\subsection{Horizontal and Vertical Distribution of Heavy Metals}

\subsubsection{Horizontal Distribution of Heavy Metals}

Heavy metals are natural crystalline compounds that originate from igneous, metamorphic rocks, and sometimes sedimentary rocks, and are transported by rivers as a result of erosion and the erosion of the parent rocks. Heavy metals undergo a recycling phase as a result of the erosion of these rocks, which in turn become secondary source rocks for these minerals (Morton \& Hallsworth, 1999). Thus, source rocks play a fundamental role in the quality of heavy metals in river sediments, in addition to the climatic conditions prevailing in the source areas playing an important role in the changes in heavy metals. The transportation distance may also play a similar role in this process (Pettijohn, 1975). Al-Bassam \& Al-Mukhtar (2008) concluded that river torsions play a role in the concentration of some heavy metals as well as being important for the relationship of the grain size of minerals with their concentration ratios in modern river sediments. Human pollutants are directly related to the pollution of water and sediments with the advancement of mankind and practices of industry, commerce and agriculture (Al-Bassam \& Al-Mukhtar, 2008). The distribution of $\mathrm{Pb}$ in the study stations showed the following ascending order: Fallujah $>$ Heet $>$ Khalidiya $>$ Muhammadi $>$ Ramadi due to the different sources of pollution from one station to another along the Euphrates River, (Fig. 2). The most important of these are the sewage and drainage water discharged from agricultural lands fertilized with phosphate fertilizers, which are directly thrown into riverbeds, leading to an increase in the $\mathrm{Cd}$ concentration in the riverine environment (Charkhabi et al., 2008). While the vertical distribution of $\mathrm{Pb}$ in each station was adopted differently and unevenly between the layers of each station, as the concentration increased in the upper layers $(30 \mathrm{~cm}$ ), as in Fallujah and Ramadi, and decreased in the lower layers $(90 \mathrm{~cm})$, (Fig. 2). This is due to the continuous increase in pollution over time at each station. Muhammadi and Heet stations show an increase in $\mathrm{Pb}$ concentration in the depth range $(30-60 \mathrm{~cm})$. 


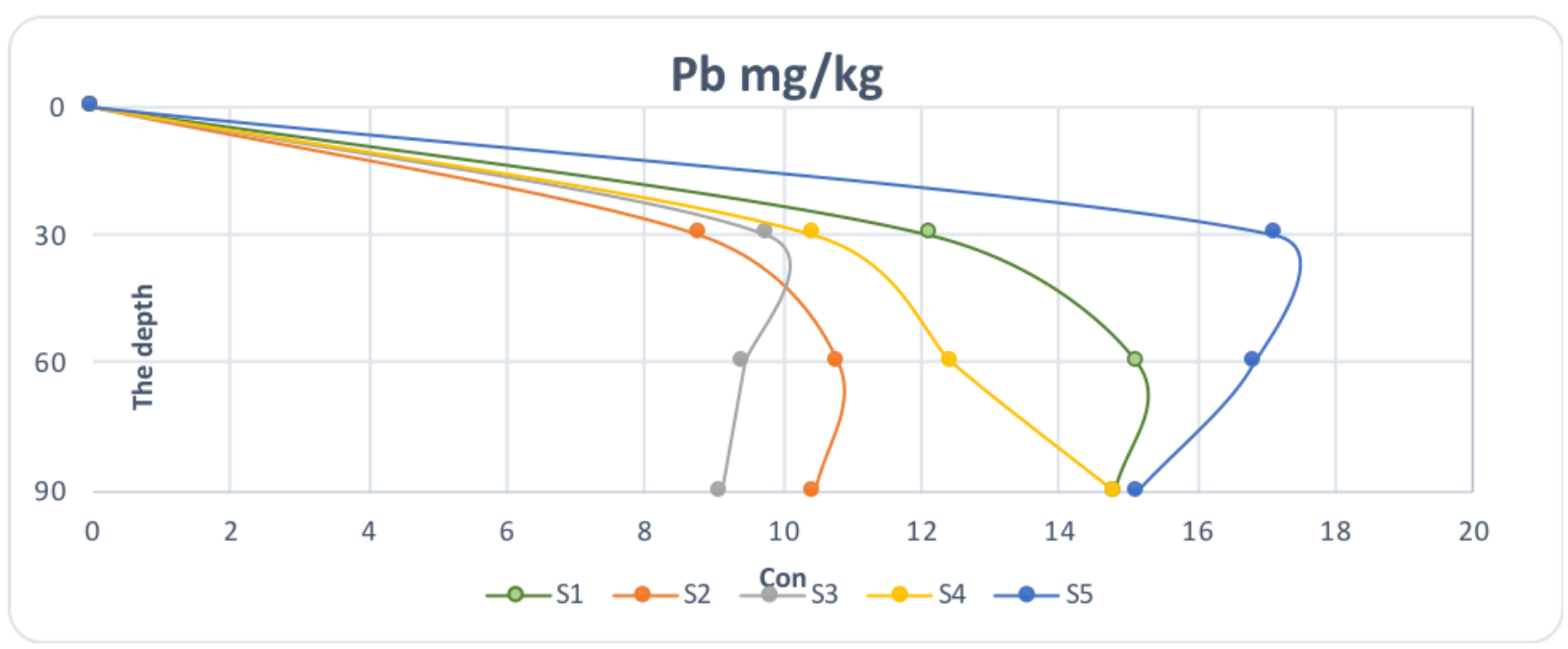

Fig. 2. Concentrations of lead $(\mathrm{mg} / \mathrm{Kg})$ in sediment of the Euphrates River

The distribution of the $\mathrm{Cd}$ in the sampling sites follows the descending order: Ramadi< Khaldiya $<$ Muhammadi $<$ Fallujah $<$ Heet. This order is due to the different sources of pollution along the Euphrates River from one station to another (Fig. 3). The vertical distribution of cadmium in each site showed different distribution patterns between the layers, with an increased concentration in the middle layers $(60 \mathrm{~cm})$, as in Heet and Muhammadi, and a decreased concentration in the other layers (Fig. 3). It increased in the upper layers $(30 \mathrm{~cm})$ from the other layers, as in Fallujah and Ramadi, and it also increased in the bottom layer $(90 \mathrm{~cm})$ from the other layers in the Khalidiya station.

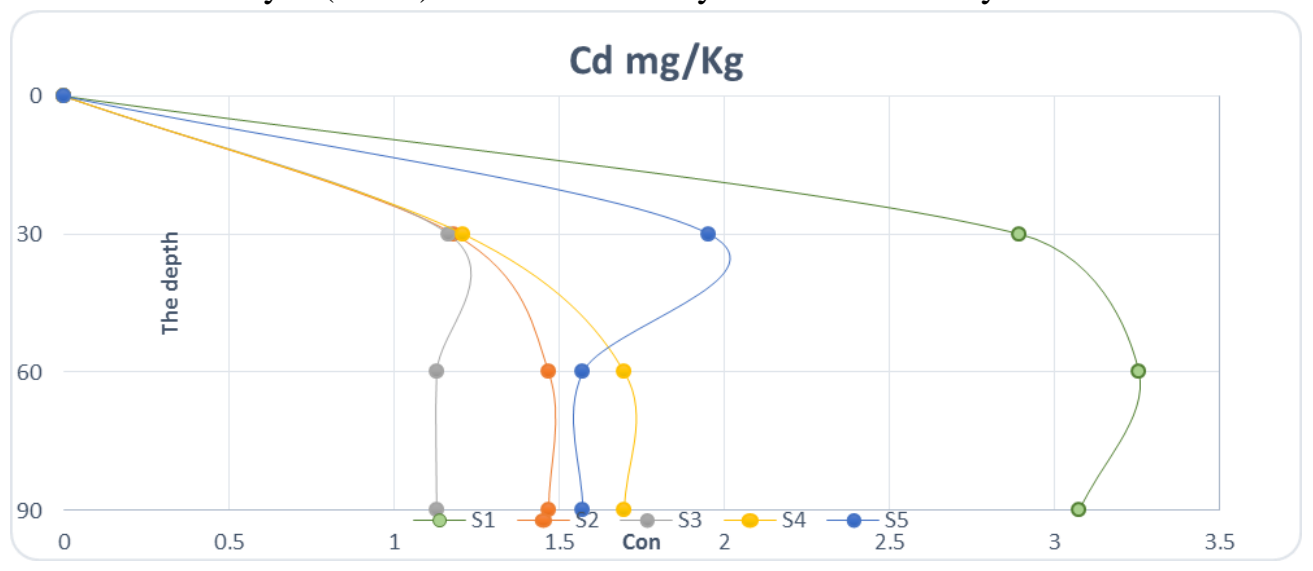

Fig. 3. Concentrations of cadmium $(\mathrm{mg} / \mathrm{Kg})$ in sediment of the Euphrates River

The results of the Fe distribution showed the following horizontal descending: Fallujah> Khaldiya> Ramadi> Muhammadi> Heet (Fig. 4). High iron concentrations are caused by the geological rock origin of the earth's crust and the accompanying processes of erosion of rocks and soil dredging that accompany torrents that enter the riverbed and lead to an increase in iron in river sediments. While the vertical distribution of iron in each station showed an upward distribution towards the lower layers in most of the stations. This is due to the natural origin of iron from the geological rocks of the earth's crust. In addition, the vertical distribution of copper in each station showed an ascending distribution towards the lower layers in all the studied stations, (Fig. 4). 


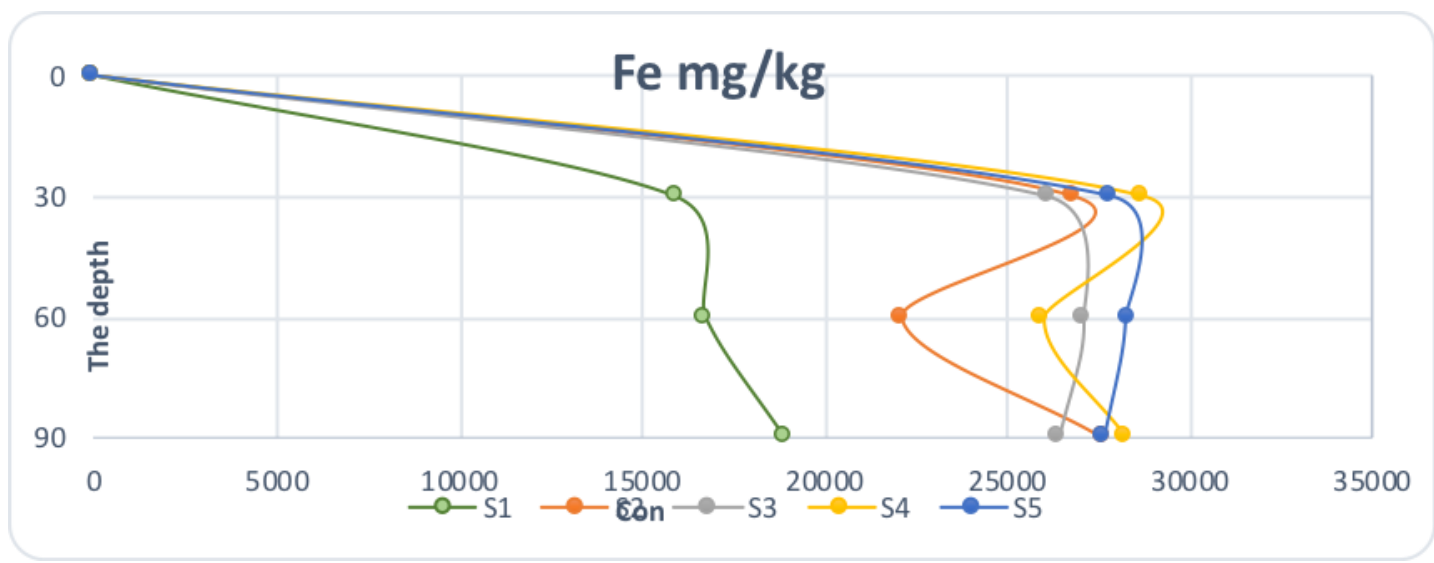

Fig. 4. Concentrations of iron $(\mathrm{mg} / \mathrm{Kg})$ in sediment of the Euphrates River

The results reveal the following horizontal distributions of $\mathrm{Cu}$ for the study stations: Muhammadi< Heet $<$ Ramadi< Khaldiya $<$ Fallujah (Fig. 5). The reason for this is the nature of the sediments of the crumbs and the torsional movement of the river's flow, erosion and weathering factors impacting sedimentary rocks, and human activity, which is represented by domestic and industrial wastewater such as thermal power stations and combustion emissions (Denton et al., 1997). In addition, the vertical distribution of copper in each station showed an ascending distribution towards the lower layers in all the studied stations (Fig. 5), the being the rocky origin of copper and the components of the earth's crust, considered a relatively abundant element in the lithosphere (Callender, 2000).

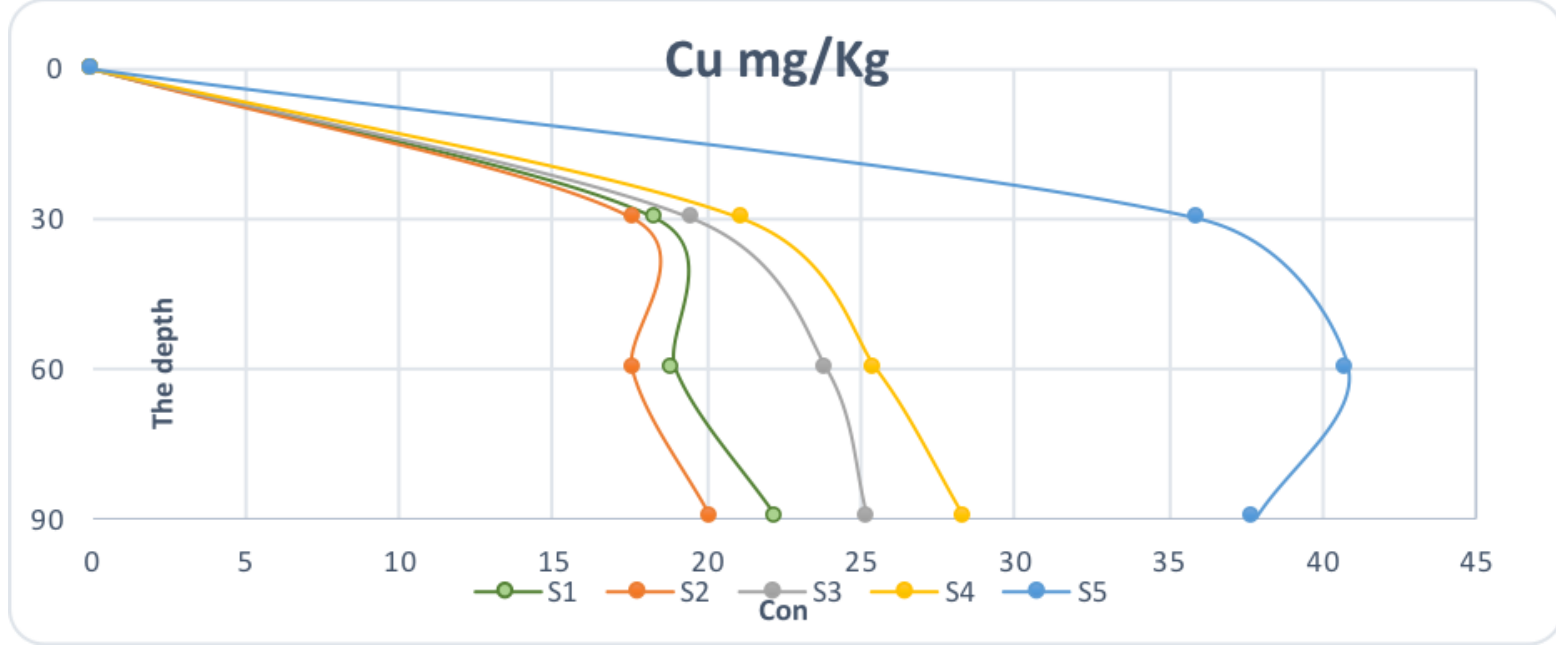

Fig. 5. Concentrations of copper $(\mathrm{mg} / \mathrm{Kg})$ in sediment of the Euphrates River

The $\mathrm{Zn}$ element distribution in the study was taken was as follows: Ramadi< Muhammadi< Al-Khalidiya $<$ Heet $<$ Fallujah (Fig. 6). The difference in concentration among the study stations, as well as the geological differences and the natural origin of the element according to the nature of the area, erosion factors and weather conditions, are due to the different sources of pollution along the Euphrates River, the most important of which are sewage and industrial water, mining operations and burning coal (Gautam et al., 2014). As for the vertical distribution of the zinc element in each station, it differed between the layers, and there were no significant differences for the zinc in the layers for each station, (Fig. 6.). 


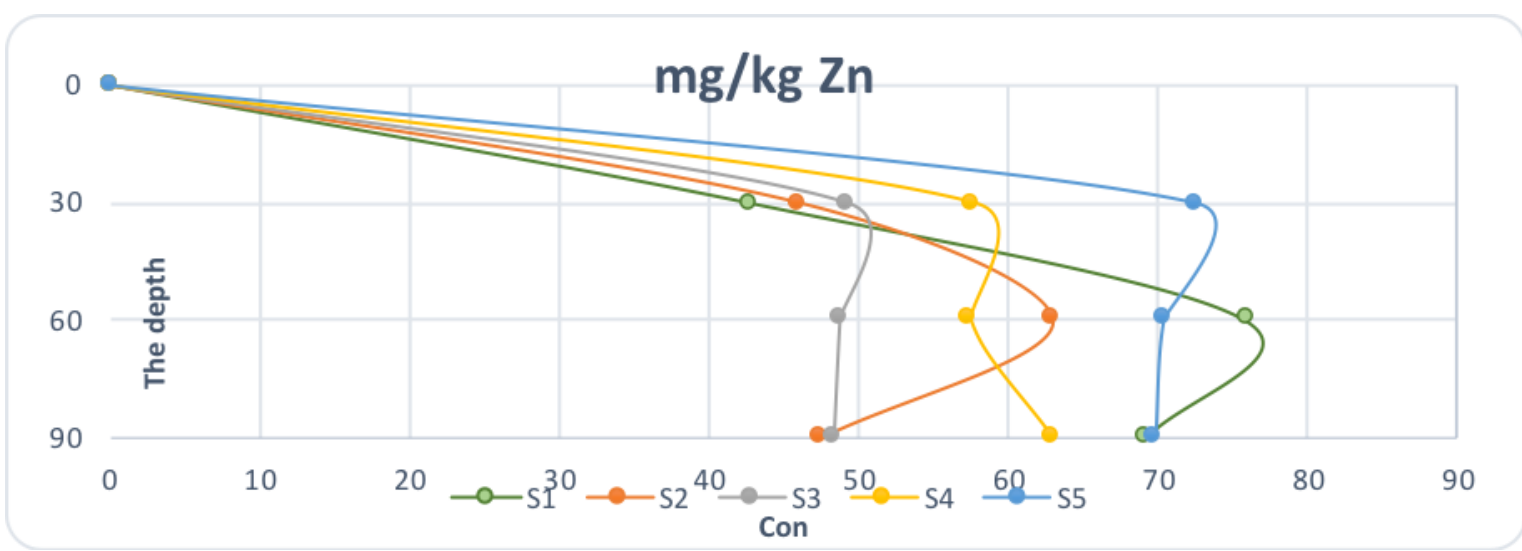

Fig. 6. Concentrations of $\mathrm{Zn}(\mathrm{mg} / \mathrm{Kg})$ in sediment of the Euphrates River

The distribution of $\mathrm{Cr}$ for the study stations showed the following descending order: Fallujah> Muhammadi> Khalidiya > Ramadi> Heet (Fig. 7). The presence of chromium comes mainly from the rocky origin of the earth's crust and the impact of environmental and climatic factors such as erosion, weathering and redistribution according to river movements, in addition to human activity represented by water discharges, sanitation and industrial waste. While the vertical distribution of chromium in each station, it showed a different variation in each station, rising in the lower layers $(90 \mathrm{~cm})$, as in Heet and Muhammadi, and decreasing in the other layers, as well as rising in the middle layers $(60 \mathrm{~cm})$, as in Khalidiya and Fallujah, and rising in the upper layer $(30 \mathrm{~cm})$ (Fig. 7). As in the Ramadi station, most of the elevation in the lower and middle layers is due to the rocky origin of the element and the impact of transport and river movements, in addition to the movement of aquatic organisms, leading to a redistribution between the layers (Sindern et al., 2016). In addition, the increase in the upper layers may be due to the increase in human pollutants excreted from industrial waste and sewage water.

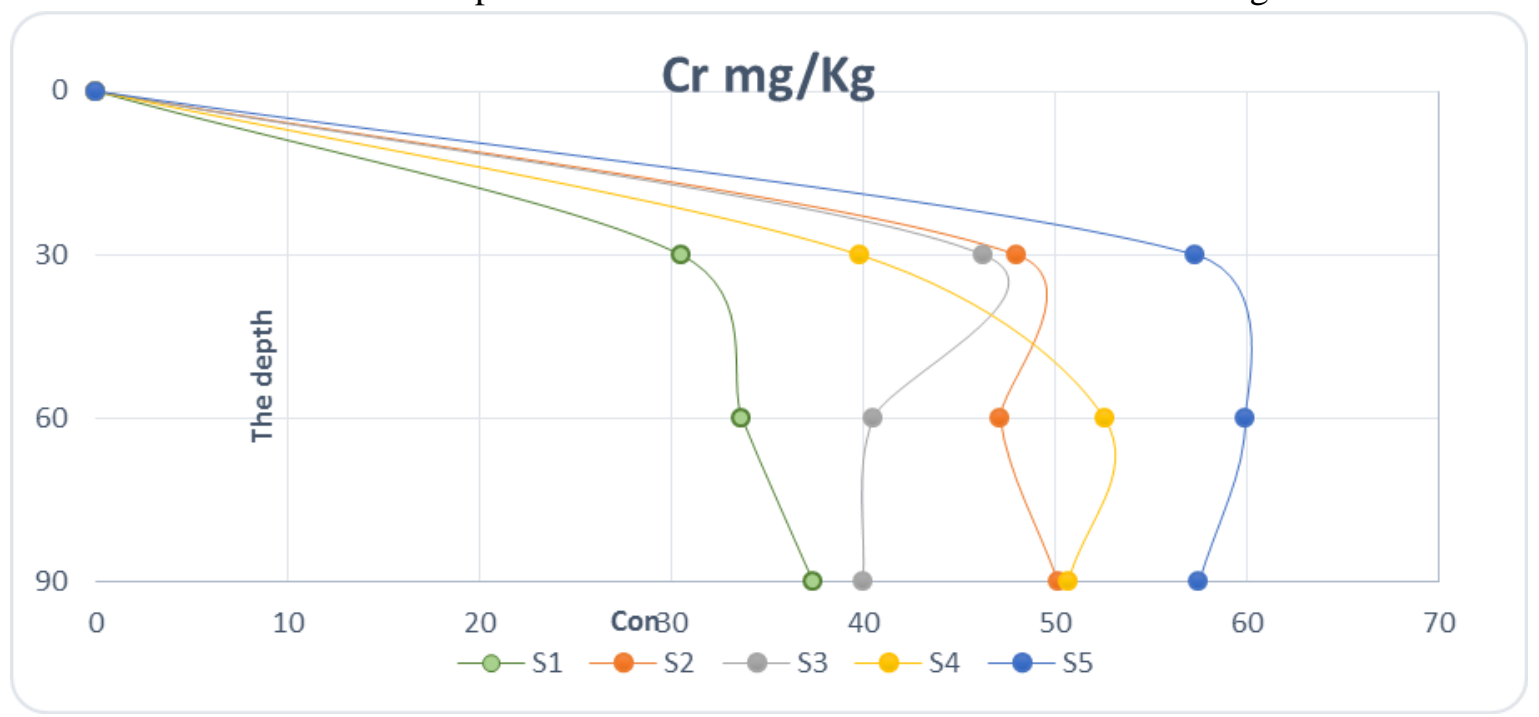

Fig. 7. Concentrations of $\mathrm{Cr}(\mathrm{mg} / \mathrm{Kg})$ in sediment of the Euphrates River

The results for the distribution of Co for the study stations showed the following horizontal order: Fallujah > Khaldiyah> Ramadi> Muhammadi > Heet, (Fig. 8). The main reason for this successive difference or increase is the natural resources and the nature of the rocks and sediments that make up the area of each station, in addition to human activity factors represented by wastewater and industrial waste, (Rosenberg, 2015). While the vertical distribution of the cobalt element in each station also showed an upward distribution towards the lower layers in all stations due to the geological rock origin 
and its high content in geological formations and the environmental and climatic conditions these formations suffer from that change the behavior of division in river sediments (Sindern et al., 2016).

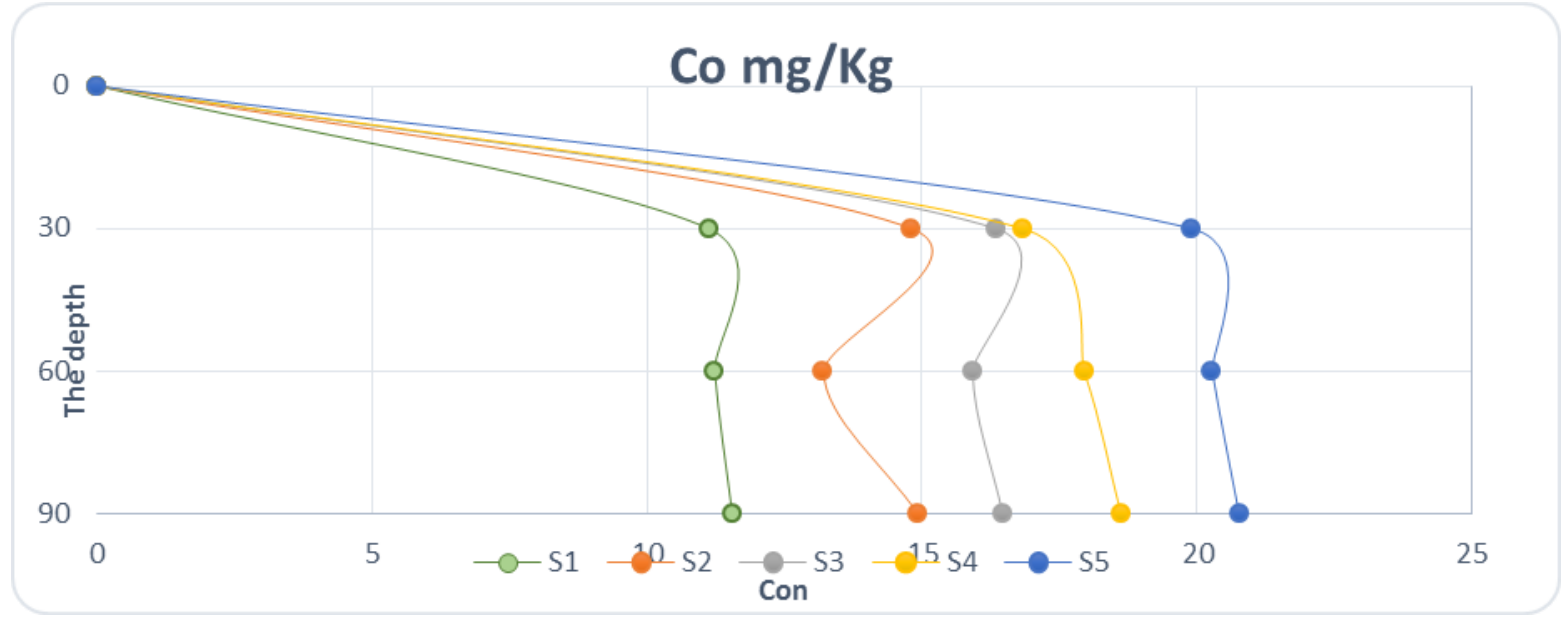

Fig. 8. Concentrations Co. $(\mathrm{mg} / \mathrm{Kg})$ in sediment of the Euphrates River

The distribution of $\mathrm{Ni}$ in the study stations showed the following ascending order: Heet< Muhammadi< Ramadi< Khalidiya < Fallujah (Fig. 9). Due to the geological rock origin and its high content in geological formations and environmental and climatic conditions, these formations suffer from changes in the behavior of division in river sediments (Sindern et al., 2016).

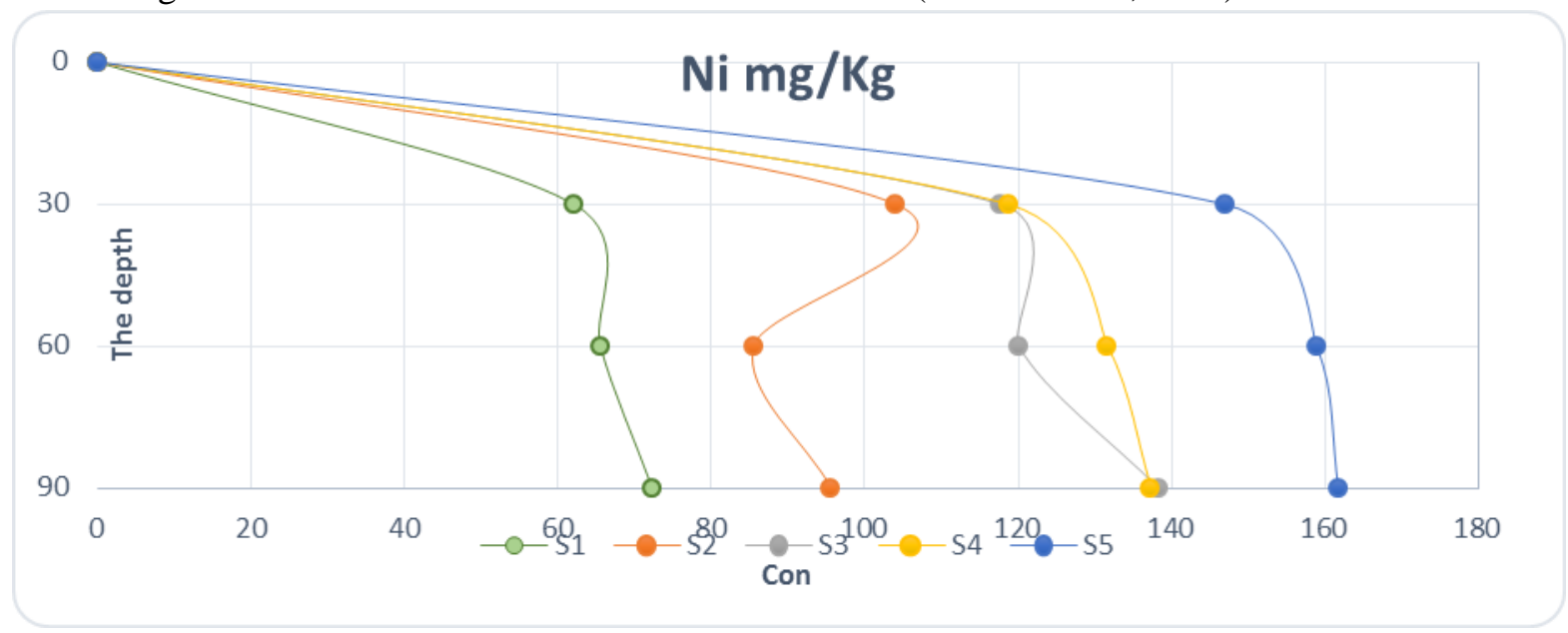

Fig.9. Concentrations of $\mathrm{Ni}(\mathrm{mg} / \mathrm{Kg})$ in sediment of the Euphrates River

In general, the continuous or escalating increase in the concentrations of heavy elements from the city of Heet to the city of Fallujah are attributable to the movement of the river and the torsions that exist along the river and the elements carried by the river's water of elements that may be gradually deposited. This is in addition to the human waste that is thrown into the river without any prior treatment. In addition, the vertical distribution of nickel in each station also showed an upward distribution towards the lower layers in most stations, except for Muhammadi station, Fig. The reason for this is due to the natural origin of nickel in the rocks of the earth's crust as well as it being a natural component of the soil, plus the accompanying factors of erosion, weathering, torrential water and rain and what is carried from the elements that eventually drain into the river, leading to increased nickel in the sedimentary strata of the river (Rosenberg, 2015; Al-Bassam \& Al-Mukhtar, 2008). In general, there were no significant differences between the layers in each station, the possible reason being the external processes that result from the movement of the river and changes in the $\mathrm{pH}$ value of the water, which causes re-dissolution and sedimentation between the sedimentary layers,transfer operations as a result of 
the movement of aquatic organisms inside the bottom of the sediments, as well as the changing the state of sediments due to grazing, excavations, and the like ( Khalid, 1980). Most of the increase in cadmium concentrations in river sediments, in addition to the geological origin of rocks, erosion factors, and air transport to industrial and agricultural human activity, as the release of heavy municipal water into rivers without treatment is one of the causes of increased pollution (Rauf et al., 2009).

\subsubsection{Vertical Distribution of Heavy Metals}

The distribution of the concentrations of the heavy metals for all depths in the sediment samples of Euphrates River was dependent on the following horizontal arrangement $\mathrm{Ni}<\mathrm{Zn}<\mathrm{Cr}<\mathrm{Cu}<\mathrm{Co}<\mathrm{Pb}<$ Cd (Fig. 10). It was observed that there were slight differences in the concentrations of heavy elements between the three layers $(0-30 \mathrm{~cm}),(30-60 \mathrm{~cm})$, and $(60-90 \mathrm{~cm})$, indicating that there were no sources of high pollution in that time period. In general, we notice an increase in the concentrations of the heavy metals towards the Fallujah station, that is, an increase from upstream to downstream in sediment samples of Euphrates River.

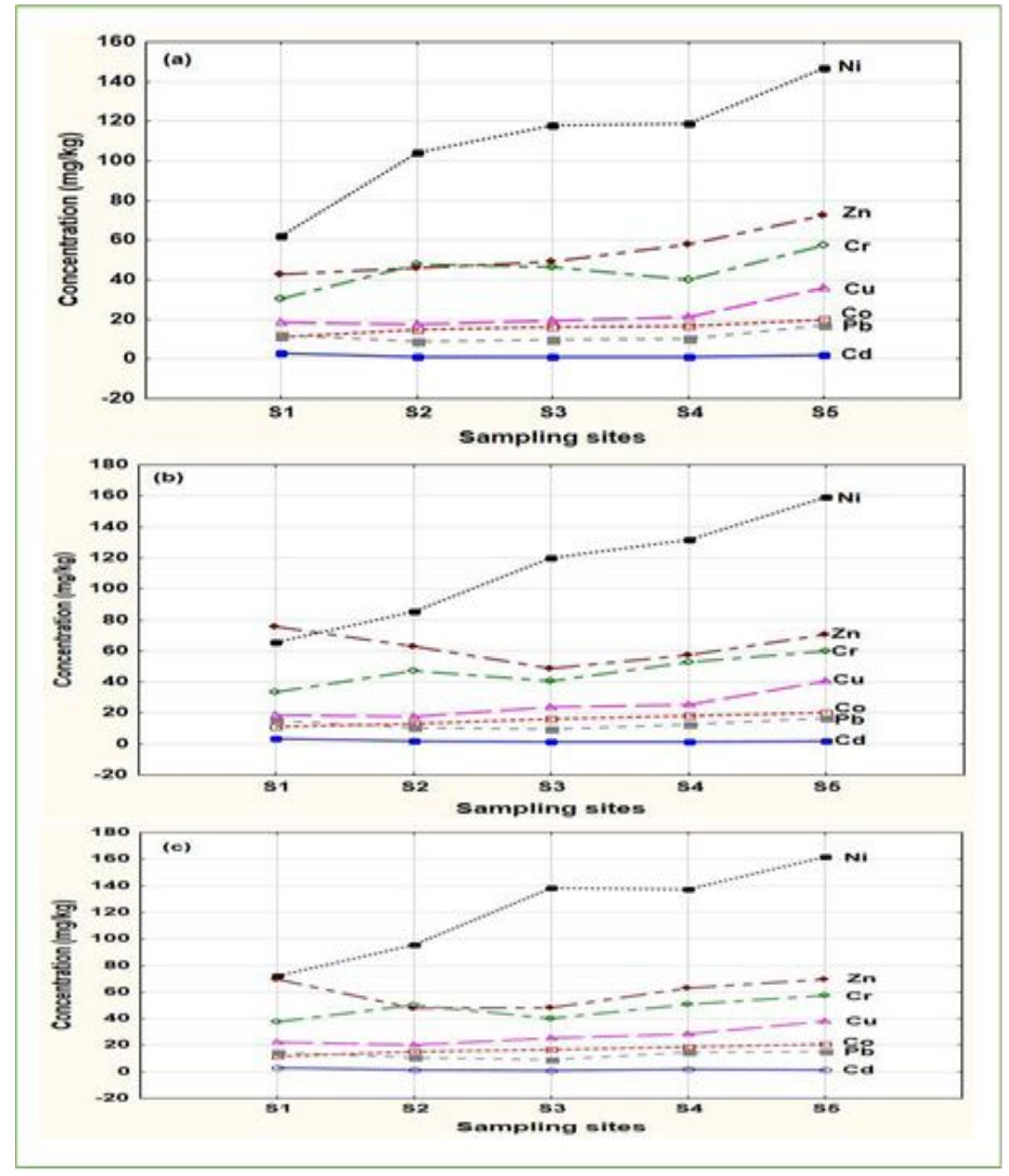

Fig. 10. A) The vertical distribution in sediment sample of Euphrates River in 30 layers; b) the vertical distribution in sediment sample of Euphrates River in 60 layers; c) the vertical distribution in sediment sample of Euphrates River in 90 layers

\subsection{Pollution Levels for Sediment of the Euphrates River}

An assessment of elemental contamination was carried out at the selected study stations to determine the state of the river. Expressions of concentration are insufficient for investigating the 
presence or absence of contamination. Therefore, pollution indicators were used to express the terms 'polluted' or 'non-polluted'. In general, the evaluation revealed the presence of moderate to low pollution in all the study stations. This pollution or increase in the concentration of some elements is due to the sedimentary layers and the pollutants carried by torrents that end up in the river, as well as, possibly, human activity, as in the increase in cadmium resulting from the use of phosphate fertilizers and the drainage of agricultural drainage water into the river water. The EF was used to distinguish between heavy metals caused by human activities and those resulting from natural formation (Fig. 11). The results indicate that all metals are deficient to minimally enriched in Euphrates River sediments. $(\mathrm{EF}<2)$, with the exception of samples of cadmium, which showed a high level of enrichment $(\mathrm{EF}<34)$ in all stations. Ni showed a moderate level of enrichment $(2 \leq \mathrm{EF}<5)$. The Igeo was used to evaluate the stages of pollution of heavy metals in sediment samples for the study area (Fig. 11). The results for the studied sediment samples of the Euphrates river showed the values of the averages of the geochemical accumulation factor for $\mathrm{Cd}$ (1.722), $\mathrm{Cr}$ (-0.852), $\mathrm{Cu}(-0.686), \mathrm{Ni}(0.398), \mathrm{Pb}(-0.66733)$, $\mathrm{Co}(-0.21), \mathrm{Zn}(-1.182)$, and $\mathrm{Fe}(-0.79533)$.

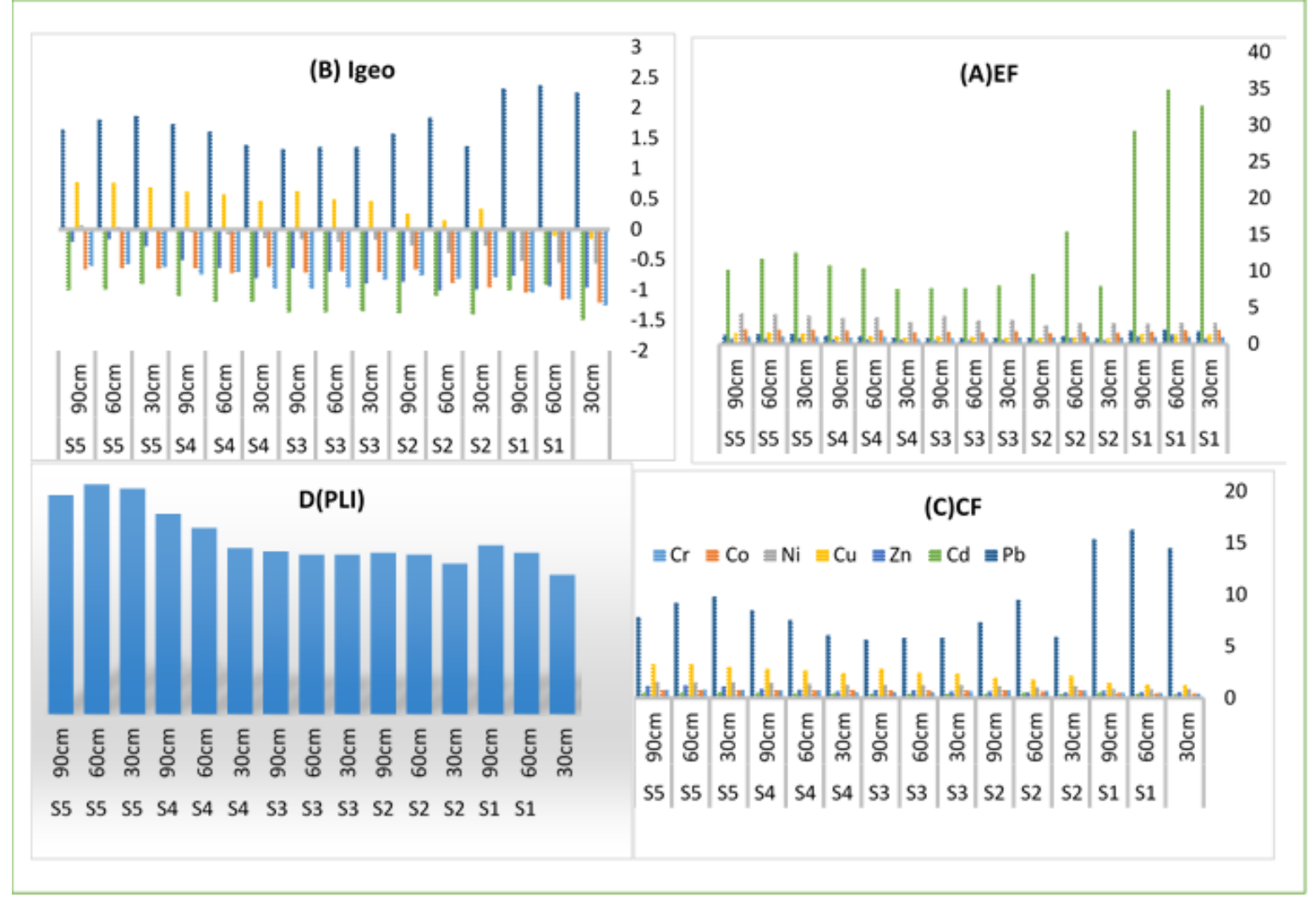

Fig.11. EF, Igeo, CF and PLI for sediment samples of the Euphrates river

The results indicate that the sediment samples for the Euphrates River are not contaminated with the following elements: $\mathrm{Cr}, \mathrm{Cu}, \mathrm{Ni}$, and $\mathrm{Zn}$, while lead contamination belongs to the unpolluted to moderately polluted category. In the case of $\mathrm{Cd}, \mathrm{Ni}$ and $\mathrm{Co}$, they belong to the heavily polluted category. The accumulation of heavy metals in sediment samples of the Euphrates River may be due to various human activities. The PLI evaluates the stage of total contamination in sediment samples for the study area. Fig. 11 shows the results of the PLI for the eight metals studied in sediment samples, with a mean value of 1.128667 and a range between 0.89 and 1.47. Based on the results presented, the degree of contamination by the eight metals in all sediment samples of the Euphrates River is classified as class 2 (deterioration on site quality), which indicates that for the studied sediment samples the Euphrates River is contaminated. 


\section{Conclusions}

The increase of the concentrations of the studied elements in the sediments of the Euphrates River in the studied area is due to the rock origin of the elements in addition to the factors of erosion, weathering, and torrents. The continuous or escalating increase in the concentrations of heavy elements from the city of Heet to the city of Fallujah is attributable to the movement of the river and the torsions that exist along the river and the elements carried by the river's water of elements that may be gradually deposited. This is in addition to the human waste that is thrown into the river without any prior treatment. The results of the study showed that iron, nickel, cobalt, chromium and copper, which are natural in origin, increase vertically towards the lower layers. As for cadmium, lead and zinc, which are both natural and human sources, they increase vertically towards the upper layers, affected by human activities that cause pollution. Enrichment factor for assessing pollution showed that most of the stations have low to medium pollution. This indicator proves the absence of human activities in the industrial field in that time period.

\section{Acknowledgements}

The authors sincerely appreciate help of the workers in the service laboratory of the Anbar College of Science, and I am also very grateful to the workers in the Anbar Water Directorate laboratory. So, we would like to thank Dr. Kamal Alparuany for his help. The authors are very grateful to the Editor in Chief Prof. Dr. Salih M. Awadh, the Secretary of Journal Mr. Samir R. Hijab. and the Technical Editors for their great efforts and valuable comments.

\section{References}

Al-Bassam, K. S., 2011. Environmental factors influencing spatial distribution of cadmium in the Euphrates river sediments in Iraq. Iraqi Bulletin Of Geology And Mining, 7(2), 29-41.

Al-Bassam, K. S., and Al-Mukhtar, L. A., 2008. Heavy minerals in the sediments of the Euphrates River, in Iraq. Iraqi Bulletin of Geology and Mining, 4(1), 29-41.

Al-Taher, Q. M., Akbar, M. M., and Al-Qarooni, I. H., 2020. Estimation of heavy metals in water, sediments and bioaccumulation in two species of mollusca: Clam pseudodontopsis euphraticus and snail bellamya bengalensis in euphrates river in al-nasiriyah city, south of Iraq. Plant Archives, 20, 1454-1460.

Callender, E.,2000. Geochemical effects of rapid sedimentation in aquatic systems: Minimal diagenesis and the preservation of historical metal signatures. Journal of Paleolimnology, 23(3), 243-260.

Chakravarty, M., and Patgiri, A. D.,2009. Metal pollution assessment in sediments of the Dikrong River, N.E. India. Journal of Human Ecology, 27(1), 63-67.

Charkhabi, A. H., Sakizadeh, M., and Bayat. R.,2008. Land use effects on heavy metal pollution of river sediments in Guilan, southwest of the Caspian sea. Caspian Journal of Environmental Sciences, 6(2), 133-140.

Chen, H., Chen, R., Teng, Y., and Wu. J.,2016. Contamination characteristics, ecological risk and source identification of trace metals in sediments of the Le'an River (China). In Ecotoxicology and Environmental Safety, 125, 85-92.

Denton, G. R. W., Wood, H. R., Concepcion, L. P., Eflin, V. S., Narcis, D. K., and Pangelinan, G. T.,1997. Analysis of in-place contaminants in marine sediments from four harbor locations on Guam. 81, 120.

dos Santos, N. M., do Nascimento, C. W. A., and de Aguiar Accioly, A. M.,2017. Guideline values and metal contamination in soils of an environmentally impacted bay. In Water, Air, and Soil Pollution, 228 (3).

EPA Method 3050B Acid Digestion of Sediments, Sludges and Soils (Issue October, p. 2012). (2012).

Gabrielyan, A. V., Shahnazaryan, G. A., and Minasyan, S. H., 2018. Distribution and identification of sources of heavy metals in the voghji river basin impacted by mining activities (Armenia). Journal of Chemistry, 1-9.

Gao, L., Gao, B., Xu, D., Peng, W., and Lu, J.,2019. Multiple assessments of trace metals in sediments and their response to the water level fluctuation in the Three Gorges Reservoir, China. Science of the Total Environment, 648, 197-205. 
Gautam, R. K., Sharma, S. K., Mahiya, S., and Chattopadhyaya, M. C.,2014. Contamination of heavy metals in aquatic media: transport, toxicity and technologies for remediation. In Heavy Metals In Water, 1-24.

Guan, J., Wang, J., Pan, H., Yang, C., Qu, J., Lu, N., and Yuan, X.,2018. Heavy metals in Yinma River sediment in a major Phaeozems zone, Northeast China: Distribution, chemical fraction, contamination assessment and source apportionment. Scientific Reports, 8(1), 1-11.

Hsu, L. C., Huang, C. Y., Chuang, Y. H., Chen, H. W., Chan, Y. T., Teah, H. Y., Chen, T. Y., Chang, C. F., Liu, Y. T., and Tzou, Y. M.,2016. Accumulation of heavy metals and trace elements in fluvial sediments received effluents from traditional and semiconductor industries. Scientific Reports, 6(101), 1-12.

Hussain, M. L., and Al-Jaberi, M. H.,2020. Comparison the bed sediment contamination of the southern part of euphrates river with Shatt Al-Arab, Iraq. In Iraqi Geological Journal, 53 (1), 68-89.

Islam, M. S., Ahmed, M. K., Raknuzzaman, M., Habibullah-Al-Mamun, M., and Kundu, G. K.,2017. Heavy metals in the industrial sludge and their ecological risk: A case study for a developing country. Journal of Geochemical Exploration, 172, 41-49.

Islam, M. S., Ahmed, M. K., Raknuzzaman, M., Habibullah -Al- Mamun, M., and Islam, M. K.,2015. Heavy metal pollution in surface water and sediment: A preliminary assessment of an urban river in a developing country. In Ecological Indicators, 48, 282-291).

Issa, M. J., and Qanbar, A. S.,2016. Assessment of heavy metal contamination in Euphrates River Sediments from Al-Hindiya Barrage to Al-Nasiria City, South Iraq, 57 (1), 184-193.

Jin, Z., Ding, S., Sun, Q., Gao, S., Fu, Z., Gong, M., Lin, J., Wang, D., and Wang, Y., 2019. High resolution spatiotemporal sampling as a tool for comprehensive assessment of zinc mobility and pollution in sediments of a eutrophic lake. Journal of Hazardous Materials, 364, 182-191.

Kanda, A., Ncube, F., Hwende, T., and Makumbe, P.,2018. Assessment of trace element contamination of urban surface soil at informal industrial sites in a low-income country. In Environmental Geochemistry and Health, 40 (6), 2617-2633.

Khalid, R.A., 1980. Chemical Mobility of Cadmium in Sediment-Water Systems. In: J.O., Nriagu (Ed.). Cadmium in the Environment, 257- 304.

Liu, J. J., Ni, Z. X., Diao, Z. H., Hu, Y. X., and Xu, X. R.,2018. Contamination level, chemical fraction and ecological risk of heavy metals in sediments from Daya Bay, South China Sea. Marine Pollution Bulletin, 132-139.

Machado, K. S., Ferreira, P. A., Rizzi, J., Figueira, R., and Froehner, S.,2017. Spatial and temporal variation of heavy metals contamination in recent sediments from Barigui River Basin, South Brazil. Environment Pollution and Climate Change, 01(01), 1-9.

Martin, J., and Meybeck, M.,1979. Sampling procedures; An outline of sampling procedures is given in Table I. Whenever possible, Marine Chemistry, 7, 173-206.

Mmolawa, K. B., Likuku, a S., and Gaboutloeloe, G. K.,2011. Assessment of heavy metal pollution in soils along major roadside areas in Botswana. Journal Environment Science and Technology, 5, 186-196.

Morton, A. C., and Hallsworth, C. R.,1999. Processes controlling the composition of heavy mineral assemblages in sandstones. Sedimentary Geology, 124(1-4), 3-29.

Müller, G.,1969. Index of geoaccumulation in sediments of the Rhine River. Geology Journal, 2, 108-118.

Nawrot, N., Wojciechowska, E., Matej-Łukowicz, K., Walkusz-Miotk, J., and Pazdro, K.,2020. Spatial and vertical distribution analysis of heavy metals in urban retention tanks sediments: a case study of Strzyza Stream. Environmental Geochemistry and Health, 42 (5), 1469-1485.

Petrosyan, V., Pirumyan, G., and Perikhanyan, Y.,2019. Determination of heavy metal background concentration in bottom sediment and risk assessment of sediment pollution by heavy metals in the Hrazdan River (Armenia). Applied Water Science, 9(4), 1-9.

Pettijohn, F. J.,1975. Sedimentary Rocks, Third Edition. Geoscience Canada, 2(4).

Raj, D., Chowdhury, A., and Maiti, S. K.,2017. Ecological risk assessment of mercury and other heavy metals in soils of coal mining area: A case study from the eastern part of a Jharia coal field, India. Human and Ecological Risk Assessment, 23(4), 767-787.

Rauf, A., Javed, M., Ubaidullah, M., and Abdullah, S.,2009. Assessment of heavy metals in sediments of the river Ravi, Pakistan. International Journal of Agriculture and Biology, 11(2), 197-200. 
Rosenberg, E.,2015. Heavy metals in water: presence, removal and safety. Johnson Matthey Technology Review, 59(4), 293-297.

Salah, E. A. M., Zaidan, T. A., and Al-Rawi, A. S.,2012. Assessment of heavy metals pollution in the sediments of Euphrates River, Iraq. Journal of Water Resource and Protection, 04(12), 1009-1023.

Sindern, S., Tremöhlen, M., Dsikowitzky, L., Gronen, L., Schwarzbauer, J., Siregar, T. H., Ariyani, F., and Irianto, H. E.,2016. Heavy metals in river and coast sediments of the Jakarta Bay region (Indonesia) — Geogenic versus anthropogenic sources. Marine Pollution Bulletin, 110(2), 624-633.

Sinex, S. A., and Helz, G. R.,1981. Regional geochemistry of trace elements in Chesapeake Bay sediments. In Environmental Geology, 3 (6), 315-323.

Tang, W., Shan, B., Zhang, H., Zhang, W., Zhao, Y., Ding, Y., Rong, N., and Zhu, X., 2014. Heavy metal contamination in the surface sediments of representative limnetic ecosystems in eastern China. Scientific Reports, 4, 1-7.

Tang, W., Sun, L., Shu, L., and Wang, C., 2020. Evaluating heavy metal contamination of riverine sediment cores in different land-use areas. Frontiers of Environmental Science and Engineering, 14(6).

Vane, C. H., Turner, G. H., Chenery, S. R., Richardson, M., Cave, M. C., Terrington, R., Gowing, C. J. B., and Moss-Hayes, V.,2020. Trends in heavy metals, polychlorinated biphenyls and toxicity from sediment cores of the inner River Thames estuary, London, UK. Environmental Science: Processes and Impacts, 22(2), 364-380.

Varol, M., Canpolat, Ö., Eriş, K. K., and Çağlar, M.,2020. Trace metals in core sediments from a deep lake in eastern Turkey: Vertical concentration profiles, eco-environmental risks and possible sources. Ecotoxicology and Environmental Safety, 189.

Ye, Z., Chen, J., Gao, L., Liang, Z., Li, S., Li, R., Jin, G., Shimizu, Y., Onodera, S. ichi, Saito, M., and Gopalakrishnan, G.,2020. 210Pb dating to investigate the historical variations and identification of different sources of heavy metal pollution in sediments of the Pearl River Estuary, Southern China. Marine Pollution Bulletin, 150 .

Zhao, S., Feng, C., Yang, Y., Niu, J., and Shen, Z., 2012. Risk assessment of sedimentary metals in the Yangtze Estuary: New evidence of the relationships between two typical index methods. Journal of Hazardous Materials, 241-242, 164-172. 